\title{
Effects of partially replacing barley silage or barley grain with dried distillers grains with solubles on rumen fermentation and milk production of lactating dairy cows
}

\author{
S. Z. Zhang, ${ }^{*}$ G. B. Penner, ${ }^{* 1}$ W. Z. Yang,, and M. Oba* ${ }^{* 2}$ \\ *Department of Agricultural, Food and Nutritional Science, University of Alberta, Edmonton, AB, T6G 2P5, Canada \\ †Agriculture and Agri-Food Canada, Research Centre, Lethbridge, AB, T1J 4B1, Canada
}

\begin{abstract}
Dried distillers grains with solubles (DDGS) has been commonly used as a dietary protein source for lactating dairy cows. However, there is a paucity of data evaluating the use of DDGS as a partial replacement of forage or grain. The objective of this study was to determine the effects of partially replacing barley silage or barley grain with corn/wheat-based DDGS on dry matter intake (DMI), chewing activity, rumen fermentation, and milk production. Six ruminally cannulated lactating Holstein cows were used in a replicated $3 \times$ 3 Latin square design with 21-d periods. Cows were fed the control diet (CON: $45 \%$ barley silage, $5 \%$ alfalfa hay, and $50 \%$ concentrate mix), a low forage (LF) diet or a low grain (LG) diet, in which barley silage or barley grain was replaced by DDGS at $20 \%$ of dietary dry matter, respectively. All diets were formulated to contain $18 \%$ crude protein and fed as total mixed rations. Compared with CON, cows fed the LF diet had greater DMI (26.0 vs. $22.4 \mathrm{~kg} / \mathrm{d})$, yields of milk (36.4 vs. $33.0 \mathrm{~kg} / \mathrm{d})$, milk protein (1.18 vs. $1.05 \mathrm{~kg} / \mathrm{d}$ ), and milk lactose (1.63 vs. $1.46 \mathrm{~kg} / \mathrm{d})$, but milk fat yield was not affected. The LF diet decreased chewing time compared with the CON diet (29.7 vs. $39.1 \mathrm{~min} / \mathrm{kg}$ of DMI), but did not affect rumen $\mathrm{pH}$ and duration of rumen $\mathrm{pH}$ below 5.8. Compared with $\mathrm{CON}$, feeding the LG diet tended to increase minimum and maximum rumen $\mathrm{pH}$, but did not affect DMI, milk yield, and milk composition in this study. These results indicate that a partial replacement of barley silage with DDGS can improve the productivity of lactating dairy cows without negatively affecting rumen fermentation and milk fat production. Barley grain can also be partially replaced by DDGS in diets for lactating dairy cows without causing negative effects on productivity.
\end{abstract}

\footnotetext{
Received December 17, 2009.

Accepted March 31, 2010.

${ }^{1}$ Current address: Department of Animal and Poultry Science, University of Saskatchewan, Saskatoon, SK, S7N 5A8, Canada.

${ }^{2}$ Corresponding author: moba@ualberta.ca
}

Key words: barley silage, barley grain, dried distillers grains with solubles

\section{INTRODUCTION}

Dried distillers grains with solubles (DDGS) is high in CP concentration and has been commonly used as a dietary protein source for lactating dairy cows. In addition to its high CP concentration, DDGS is also high in NDF content, ranging from 32\% (Anderson et al., 2006) to $44 \%$ (Kleinschmit et al., 2006) with an average of $38 \%$ (NRC, 2001). Because of the high NDF content, DDGS may be used as a partial replacement of forage for ruminants. However, physical characteristics such as small particle size and high particle density result in lower physical effectiveness compared with forages (Clark and Armentano, 1993). There are currently a limited number of studies evaluating the potential of using DDGS as a partial replacement for forage. Penner et al. (2009) reported an increase in milk production for dairy cows fed wet wheat/corn distillers grains as a partial replacement of barley silage, but also reported decreased milk fat concentration and total chewing activity. These data imply that partial replacement of barley silage with distillers grains may predispose cows to rumen acidosis. However, to our knowledge there is no study examining ruminal fermentation when DDGS is included as a partial replacement of forage in diets for dairy cows.

In addition to a high NDF concentration, the NDF from DDGS is highly digestible (Getachew et al., 2004), and the $\mathrm{NE}_{\mathrm{L}}$ value of DDGS is high: 1.94 and 2.35 $\mathrm{Mcal} / \mathrm{kg}$ of DM for wheat- and corn-DDGS, respectively (Nuez Ortin and Yu, 2009). As such, DDGS may serve as an energy source partially replacing grain in diets for lactating dairy cows. In addition, as the starch concentration of DDGS is lower than grain, partially replacing grain with DDGS in diets for lactating dairy cows is expected to decrease the risk of rumen acidosis. Use of DDGS as a substitute for corn grain was studied in a previous study (Grings et al., 1992). However, ef- 
fects of feeding DDGS were confounded by different dietary CP concentrations in their study. There are little data available to assess the feeding value of DDGS as an energy source for dairy cows.

The objective of this study was to evaluate the effects of partially replacing barley silage or barley grain with DDGS on DMI, milk yield and milk composition, chewing activity, and rumen fermentation of lactating dairy cows.

\section{MATERIALS AND METHODS}

\section{Animals, Diets, and Experimental Design}

This experiment was conducted at the Dairy Research and Technology Center at the University of Alberta. All procedures were preapproved by the Faculty Animal Policy and Welfare Committee at the University of Alberta and conducted according to the guidelines of the Canadian Council of Animal Care (Ottawa, Ontario, Canada).

Six multiparous lactating Holstein cows, each fitted with a ruminal cannula, were used. Cows were blocked by stage of lactation and assigned to 1 of 3 dietary treatments in a replicated $3 \times 3$ Latin square design balanced for carryover effects. Stage of lactation was used as a blocking variable because 3 cows were in mid lactation (76 $\pm 26 \mathrm{DIM} ; 605 \pm 49 \mathrm{~kg}$ of $\mathrm{BW})$ and the other 3 cows were in late lactation (244 \pm 41 DIM; 726 $\pm 67 \mathrm{~kg}$ of BW). Each period consisted of a 15-d diet adaptation period and a 6 -d data and sample collection period. The treatments were control (CON: $45 \%$ barley silage, $5 \%$ alfalfa hay, and $50 \%$ barley-based concentrate mix), and low forage ( $\mathbf{L F}$ ) and low grain (LG) diets in which barley silage or barley grain was replaced by DDGS at $20 \%$ of dietary DM, respectively (Table 1). The DDGS was produced from $70 \%$ corn and 30\% wheat (Husky Energy, Lloydmister, Saskatchewan, Canada). The same batch of DDGS was used throughout the study. Diets were formulated according to NRC (2001) to meet the nutritional requirements for a 670$\mathrm{kg}$ cow producing $40 \mathrm{~kg}$ of milk/d with $3.5 \%$ milk fat and $3.2 \%$ milk protein. Because the $\mathrm{CP}$ concentration was higher for DDGS than for barley grain or barley silage, experimental diets contained variable amounts of nonforage and nongrain feedstuffs (i.e., canola meal, corn gluten meal, beet pulp, and urea) to make the experimental diets isonitrogenous. This approach was expected to minimize confounding effects that would be caused by different dietary allocations of grain or forage when it was not evaluated as a treatment. Cows were housed individually in tie stalls and allowed to exercise for $2 \mathrm{~h}$ daily throughout the experiment except for weekends and during sample collection periods. Cows
Table 1. Ingredients of experimental diets

\begin{tabular}{lrcc}
\hline & \multicolumn{3}{c}{ Diet $^{1}$} \\
\cline { 2 - 4 } Ingredient, \% of DM & CON & LF & LG \\
\hline Alfalfa hay & 5.1 & 5.0 & 5.1 \\
Barley silage & 44.6 & 24.8 & 44.6 \\
DDGS $^{2}$ & - & 20.1 & 20.1 \\
Rolled barley & 35.2 & 35.1 & 15.1 \\
Canola meal & 3.1 & - & - \\
Corn gluten meal & 5.6 & 0.4 & 0.5 \\
Beet pulp & 2.5 & 10.8 & 11.1 \\
Urea & 0.1 & 0.2 & - \\
Premix & 1.0 & 1.0 & 1.0 \\
Limestone & 1.0 & 1.1 & 0.8 \\
Salt & 0.5 & 0.5 & 0.5 \\
Magnesium oxide & 0.1 & 0.1 & 0.1 \\
Dicalcium phosphate & 1.2 & 0.9 & 1.1 \\
\hline
\end{tabular}

${ }^{1} \mathrm{CON}=$ control; $\mathrm{LF}=$ low forage; $\mathrm{LG}=$ low grain.

${ }^{2}$ Dried distillers grains with solubles: a blend of $70 \%$ corn- and $30 \%$ wheat-based dried distillers grains with solubles; $85.4 \%$ DM, $6.2 \%$ ash, $34.1 \% \mathrm{CP}, 9.8 \%$ ether extract, and $32.8 \% \mathrm{NDF}$.

${ }^{3}$ Contained $0.10 \% \mathrm{Ca} ; 0.60 \% \mathrm{P} ; 11.50 \% \mathrm{Na} ; 0.30 \% \mathrm{Mg} ; 10 \mathrm{mg} / \mathrm{kg}$ of $\mathrm{F} ; 80 \mathrm{mg} / \mathrm{kg}$ of I; $5,000 \mathrm{mg} / \mathrm{kg}$ of Zn; 31,000 mg/kg of Mn; $1,170 \mathrm{mg} /$ $\mathrm{kg}$ of $\mathrm{Cu} ; 6.2 \mathrm{mg} / \mathrm{kg}$ of Co; 1,265 kIU/ $\mathrm{kg}$ of vitamin A; $142 \mathrm{kIU} / \mathrm{kg}$ of vitamin $\mathrm{D} ; 3,800 \mathrm{IU} / \mathrm{kg}$ of vitamin $\mathrm{E}$.

were fed experimental diets as TMR once daily at 0800 $\mathrm{h}$ and had free access to fresh water. Animals were fed at 105 to $110 \%$ of expected feed intake. The amounts of feed offered and refused were recorded daily during sample collection periods. Samples of feed ingredients and orts were collected daily during sample collection periods and composited by period for feed ingredients, and by period and by cow for orts. The DM concentrations of barley silage and alfalfa hay were determined twice weekly and used to adjust dietary formulation if necessary. Dietary forage NDF concentration was 24.2, 14.6 , and $24.4 \%$, and dietary starch concentration was $27.7,23.7$, and $17.1 \%$ for the CON, LF, and LG diets, respectively (Table 2 ).

Cows were milked twice daily at 0400 and $1600 \mathrm{~h}$. Milk was sampled at both milkings on d 19, 20, and 21 of each period. Cows were weighed after the morning milking on 2 consecutive days immediately before the start of experiment and on the last $2 \mathrm{~d}$ of each period. Body condition score was determined by 2 experienced individuals separately at the beginning of the experiment and at the end of each period using a 5-point scale $(1=$ thin and $5=$ fat; Wildman et al., 1982) and averaged.

\section{Chewing Activity and Sorting Behavior}

Chewing activities were monitored for $24 \mathrm{~h}$ on $\mathrm{d} 16$ of each period. Eating and ruminating activities were recorded every $5 \mathrm{~min}$ and each activity was assumed to continue for the entire 5-min interval between ob- 
Table 2. Nutrient composition and particle size distribution of experimental diets

\begin{tabular}{|c|c|c|c|c|c|c|}
\hline \multirow[b]{3}{*}{ Item } & \multicolumn{6}{|c|}{ Diet $^{1}$} \\
\hline & \multicolumn{2}{|c|}{$\mathrm{CON}(\mathrm{n}=3)$} & \multicolumn{2}{|c|}{$\mathrm{LF}(\mathrm{n}=3)$} & \multicolumn{2}{|c|}{$\mathrm{LG}(\mathrm{n}=3)$} \\
\hline & Mean & $\mathrm{SD}$ & Mean & $\mathrm{SD}$ & Mean & $\mathrm{SD}$ \\
\hline \multicolumn{7}{|c|}{ Composition, $\%$ of DM } \\
\hline $\mathrm{DM}, \%$ as fed & 55.5 & 0.9 & 67.1 & 1.6 & 55.5 & 1.0 \\
\hline $\mathrm{OM}$ & 91.0 & 0.9 & 90.7 & 1.8 & 91.1 & 0.5 \\
\hline $\mathrm{CP}$ & 18.8 & 0.8 & 19.6 & 0.5 & 18.8 & 0.6 \\
\hline $\mathrm{NDF}$ & 36.0 & 0.4 & 33.0 & 1.8 & 38.2 & 1.1 \\
\hline Forage NDF & 24.2 & 0.3 & 14.6 & 0.4 & 24.4 & 0.5 \\
\hline Starch & 27.7 & 0.3 & 23.7 & 1.6 & 17.1 & 1.4 \\
\hline Ether extract & 2.0 & 0.6 & 3.4 & 0.2 & 3.5 & 0.4 \\
\hline $\mathrm{NFC}^{2}$ & 34.3 & 1.4 & 34.8 & 2.1 & 30.7 & 0.3 \\
\hline \multicolumn{7}{|c|}{ Particle size distribution, $\%$ as fed } \\
\hline$>19 \mathrm{~mm}$ & 6.2 & 1.6 & 5.0 & 1.1 & 6.2 & 1.6 \\
\hline $19-8 \mathrm{~mm}$ & 41.1 & 3.0 & 28.0 & 2.2 & 41.1 & 3.0 \\
\hline$<8 \mathrm{~mm}$ & 52.7 & 4.4 & 67.1 & 3.2 & 52.7 & 4.4 \\
\hline $\mathrm{PEF}^{3}$ & 0.47 & 0.04 & 0.33 & 0.03 & 0.47 & 0.04 \\
\hline
\end{tabular}

servations. Total chewing time was calculated as the sum of eating time and ruminating time. The sorting index was calculated as the ratio of actual intake to expected intake for particles retained on each sieve of the Penn State Particle Separator (Leonardi and Armentano, 2003). A sorting index of $100,>100$, and $<100$ indicated no sorting, sorting for, and sorting against, respectively.

\section{Rumen $\mathrm{pH}$ and Rumen Fermentation}

Rumen $\mathrm{pH}$ was measured every $30 \mathrm{~s}$ for $72 \mathrm{~h}$ using an industrial electrode (model S650-CDHF, Sensorex, Garden Grove, CA) that was positioned within the ventral sac using weights. The electrode was linked to a pH data logger (model M1b-pH-1KRTD, Dascor, Escondido, CA) as described in detail by Penner et al. (2006). Rumen fluid was collected every $9 \mathrm{~h}$ over a 72-h period starting on d 16 of each experimental period (i.e., 0900 and $1800 \mathrm{~h}$ on d 16; 0300, 1200, and $2100 \mathrm{~h}$ on d 17; and 0600,1500 , and $2400 \mathrm{~h}$ on d 18). Rumen digesta were collected from the cranial, ventral, and caudal regions, and strained through a perforated material immediately after collection and placed on ice. The filtrate was centrifuged at $4^{\circ} \mathrm{C}$ at $3,000 \times g$ for 20 min and composited to yield one sample per cow per period. Samples were stored at $-20^{\circ} \mathrm{C}$ until analysis.

\section{Solid Passage Rate}

The passage rate of digesta from the rumen was estimated using Cr-mordanted fiber as solid marker ac- cording to Udén et al. (1980). On d 19 of each period, approximately $6 \mathrm{~kg}$ of rumen digesta was collected via the ruminal cannula. Subsequently, $100 \mathrm{~g}$ of Cr-mordanted fiber was mixed evenly with the collected rumen digesta and placed into several different locations of the rumen. Ruminal digesta samples were collected as described previously at $-1,0.5,1,2,3,6,9,12,18,24$, 36,48 , and $72 \mathrm{~h}$ after the dose of $\mathrm{Cr}$-mordanted fiber and solid samples were stored at $-20^{\circ} \mathrm{C}$ until analysis. For analysis, samples were thawed and dried in a forced air oven at $55^{\circ} \mathrm{C}$ for $72 \mathrm{~h}$, and ground to pass through a 1-mm screen (Thomas-Wiley, Philadelphia, PA). Samples were digested according to the procedure of Williams et al. (1962), and analyzed by an atomic absorption spectrophotometer (AA240FS, Varian Inc., Palo Alto, CA). The $\mathrm{Cr}$ concentration was fitted to the 1-compartment model (Grovum and Williams, 1973):

$$
\mathrm{Y}_{\mathrm{t}}=\mathrm{Y}_{0} \times \mathrm{e}^{-\mathrm{kt}}
$$

where $\mathrm{Y}_{\mathrm{t}}$ is the concentration of $\mathrm{Cr}$ at time $\mathrm{t}(\mathrm{mg} / \mathrm{kg})$; $\mathrm{Y}_{0}$ is the concentration of $\mathrm{Cr}$ at time $0(\mathrm{mg} / \mathrm{kg})$; $\mathrm{t}$ is the sampling time after marker dosing $(\mathrm{h})$; and $\mathrm{k}$ is the passage rate of $\mathrm{Cr}(\% / \mathrm{h})$.

\section{Apparent Total-Tract Digestibility}

Fecal samples were collected from the rectum every 9 h over a 72 -h period on d 16, 17, and 18 of each experimental period (at the same time as rumen fluid collection). Samples were composited by cow and by period, dried in forced air oven at $55^{\circ} \mathrm{C}$ for $72 \mathrm{~h}$, and ground to 
pass through a 1-mm screen (Thomas-Wiley). Indigestible NDF was used as an internal marker to calculate apparent total-tract digestibility (Cochran et al., 1986). The indigestible NDF concentration of feed ingredients, orts, and fecal samples was determined by incubating samples in the rumen for $120 \mathrm{~h}$ using nitrogen-free polyester bags $(5 \times 10 \mathrm{~cm}$, pore size $=50 \mu \mathrm{m}$; R510, Ankom Technology, Macedon, NY).

\section{Blood Metabolites}

Blood samples were collected from the coccygeal vessel using a vacutainer tube (Fisher Scientific, Franklin Lakes, NJ) containing Na-heparin every 9 h over a 72 -h period starting on d 16 of each experimental period (at the same time as rumen fluid collection). Blood samples were centrifuged at $4^{\circ} \mathrm{C}$ at $3,000 \times g$ for $20 \mathrm{~min}$. Plasma was then harvested and samples were composited to yield one sample per cow per period, and stored at $-20^{\circ} \mathrm{C}$ until analysis.

\section{Sample Analyses}

Particle size distribution of feed ingredients and orts was determined using the Penn State Particle Separator (Lammers et al., 1996). The dietary particle size distribution was calculated from the particle size distribution of individual feed ingredients and their dietary inclusion rate. The physically effective factor was defined as the proportion of particles retained on 19- and 8-mm sieves.

The composited samples of feed ingredients and orts were dried in a forced air oven at $55^{\circ} \mathrm{C}$ for $48 \mathrm{~h}$ to determine DM concentration. Dried samples were then ground to pass through a 1-mm screen using a Wiley mill (Thomas-Wiley) for chemical analysis. Analytical $\mathrm{DM}$ concentration was determined at $135^{\circ} \mathrm{C}$ for $2 \mathrm{~h}$ (AOAC, 2002; method 930.15). The OM concentration was determined by oxidizing the dry sample in a muffle furnace for $2 \mathrm{~h}$ at $600^{\circ} \mathrm{C}$ (AOAC, 2002; method 942.05). The NDF concentration was determined according to the method of Van Soest et al. (1991) using amylase and sodium sulfite. The CP concentration was determined using a Leco N analyzer (FP-2000, Leco Instrument Inc., St. Joseph, MI). The starch concentration was measured by an enzymatic method described by Karkalas (1985) after samples were gelatinized with sodium hydroxide and starch was hydrolyzed with industrial amylase; glucose concentration was measured using a glucose oxidase/peroxidase enzyme (P7119, Sigma) and dianisidine dihydrochloride (F5803, Sigma). Absorbance was determined with a plate reader (SpectraMax 190, Molecular Devices Corp., Sunnyvale, CA). Ether extract concentration was determined using a Goldfisch extraction apparatus with petroleum ether (Labconco, Kansas City, MO).

Milk samples were analyzed for fat, $\mathrm{CP}$, lactose, and MUN by infrared spectroscopy (AOAC, 2002; method 972.16; MilkoScan 605, Foss North America, Brampton, Ontario, Canada) at the Alberta Central Milk Testing Laboratory (Edmonton, AB, Canada). Period composite samples, prepared based on the yield of milk fat from each milking, were stored at $-20^{\circ} \mathrm{C}$ until fatty acid analysis. Lipids were extracted from the milk samples by the procedure described by Folch et al. (1957). The fatty acids were derivatized using methanolic base (Supelco, Bellefonte, PA) and quantified using a gas chromatography (Varian 3400, Varian Chromatography Systems, Walnut Creek, CA) with a flame-ionization detector. Separation of the fatty acid methyl esters was performed using a SP-2560 fused silica capillary column $(100 \mathrm{~m} \times 0.25 \mathrm{~mm}$ internal diameter, with 0.25 $\mu \mathrm{m}$ film thickness; Supelco). Helium was used as the carrier gas with a head pressure of $207 \mathrm{kPa}$. The initial column temperature was set at $45^{\circ} \mathrm{C}$ and held for $4 \mathrm{~min}$, increased to $175^{\circ} \mathrm{C}$ at the rate of $13^{\circ} \mathrm{C} / \mathrm{min}$ and held for $27 \mathrm{~min}$. It was finally increased to $215^{\circ} \mathrm{C}$ at the rate of $4^{\circ} \mathrm{C} / \mathrm{min}$ and held for $35 \mathrm{~min}$. The initial injector temperature was set at $50^{\circ} \mathrm{C}$ and held for $0.2 \mathrm{~min}$. Subsequently, the injector temperature was increased at a rate of $150^{\circ} \mathrm{C} / \mathrm{min}$ to $230^{\circ} \mathrm{C}$ and held for $88.6 \mathrm{~min}$. The detector temperature was held at $230^{\circ} \mathrm{C}$. Peak integration was performed using the Galaxie Chromatography Data System (Varian Chromatography Systems). The individual fatty acids were identified using the fatty acid methyl ester standard \#463 (Nu-Chek Prep, Elysian, MN). Each fatty acid was reported as grams per 100 grams of total fatty acids.

Plasma glucose concentration was measured using a glucose oxidase/peroxidase enzyme and dianisidine as described above. A commercial kit was used to determine the plasma concentration of insulin (Coat-ACount, Diagnostic Products Corp., Los Angeles, CA). The concentration of plasma urea $\mathrm{N}$ was determined enzymatically (Fawcett and Scott, 1960). Rumen fluid samples were thawed and centrifuged at $4^{\circ} \mathrm{C}$ at 26,000 $\times g$ for $15 \mathrm{~min}$. The supernatant was used for quantifying VFA concentration by gas chromatography according to the method described by Khorasani et al. (1996). Rumen ammonia N concentration was determined using a spectrophotometer (UV/VIS Spectrophotometer, V-530, Jasco Corp., Tokyo, Japan) as described by Fawcett and Scott (1960).

\section{Calculations and Statistical Analysis}

The ECM yield was calculated according to the equation described by Tyrrell and Reid (1965): ECM 
$=[0.327 \times$ milk yield $(\mathrm{kg})+12.95 \times$ fat yield $(\mathrm{kg})$ $+7.2 \times$ protein yield]. Total digestible nutrients were calculated from apparent total-tract DM digestibility according to NRC (2001), with the modifications described by Penner and Oba (2009). The total digestible nutrients were then used to calculate dietary $\mathrm{NE}_{\mathrm{L}}$ according to NRC (2001). The net energy required for maintenance was calculated as $\mathrm{NE}_{\mathrm{M}}(\mathrm{Mcal} / \mathrm{d})=0.08$ $\mathrm{Mcal} / \mathrm{kg}$ of $\mathrm{BW}^{0.75}$, and $\mathrm{NE}_{\mathrm{L}}$ was calculated according to NRC (2001) with the observed milk yield and concentrations of milk fat, milk $\mathrm{CP}$, and milk lactose according to NRC (2001): $\mathrm{NE}_{\mathrm{L}}(\mathrm{Mcal} / \mathrm{d})=$ Milk yield $\times(0.0929 \times$ milk fat $+0.0547 \times$ milk protein +0.0395 $\times$ milk lactose).

Data were analyzed using the fit model procedure of JMP (version 7.0.2, SAS Institute Inc., Cary, NC) according to the following model:

$$
\mathrm{Y}_{\mathrm{ijkl}}=\mu+\mathrm{P}_{\mathrm{i}}+\mathrm{S}_{\mathrm{j}}+\mathrm{T}_{\mathrm{k}}+\mathrm{C}(\mathrm{S})_{\mathrm{k}(\mathrm{l})}+\mathrm{e}_{\mathrm{ijk} \mathrm{k}} \text {, }
$$

where $Y_{\mathrm{ijk}}$ is the dependent variable, $\mu$ is overall mean, $\mathrm{P}_{\mathrm{i}}$ is fixed effect of period, $\mathrm{S}_{\mathrm{j}}$ is fixed effect of stage of lactation, $\mathrm{T}_{\mathrm{k}}$ is fixed effect of treatment, $\mathrm{C}(\mathrm{S})_{\mathrm{k}(1)}$ is the random effect of cows nested in the stage of lactation, and $e_{i j k l}$ is the residual. The interaction of stage $\times$ treatment had been included in the initial model, but it was removed because the interaction was not significant for primary response variables. Preplanned orthogonal contrasts were used to compare treatment means of CON versus LF and CON versus LG. Treatment effects were declared significant at $P \leq 0.05$, and a tendency was declared at $0.05<P \leq 0.10$.

\section{RESULTS}

\section{Intake, Passage Rates, and Digestibility}

Intakes of DM (26.0 vs. $22.4 \mathrm{~kg} / \mathrm{d} ; P=0.01), \mathrm{CP}(5.1$ vs. $4.2 \mathrm{~kg} / \mathrm{d} ; P=0.01)$, and ether extract (EE; 0.9 vs. $0.4 \mathrm{~kg} / \mathrm{d} ; P<0.01$ ) were higher for cows fed the LF diet than for those fed the CON diet (Table 3). Starch intake was not different between cows fed the LF and CON diets. There was no difference in DMI between cows fed the LG and CON diets. However, cows fed the LG diet had higher intakes of NDF ( 8.9 vs. $8.0 \mathrm{~kg} / \mathrm{d}$; $P=0.01)$ and EE $(0.9$ vs. $0.4 \mathrm{~kg} / \mathrm{d} ; P<0.01)$ but lower intake of starch $(4.5$ vs. $6.5 \mathrm{~kg} / \mathrm{d} ; P<0.01)$. The solid passage rate tended to be lower $(2.3$ vs. $3.6 \% / \mathrm{h}$; $P=0.08$ ) for cows fed the LF diet than for those fed the CON diet. The apparent total-tract digestibilities of DM (67.7 vs. $65.6 \% ; P=0.03), \mathrm{OM}(71.0$ vs. $69.3 \%$; $P=0.05), \mathrm{CP}(70.6$ vs. $68.3 \% ; P=0.03)$, and $\mathrm{EE}(78.4$ vs. $62.6 \% ; P<0.01)$ were higher but starch digestibility was lower (95.3 vs. $96.7 \%$; $P=0.01$ ) for cows fed the LF diet compared with those fed the CON diet. The apparent total-tract digestibility of NDF was not affected by the LF diet. Cows fed the LG diet had lower total digestibility of DM (63.3 vs. $65.6 \% ; P=0.02)$ and starch (94.1 vs. $96.7 \% ; P<0.01$ ), whereas digestibility of NDF (55.1 vs. $52.6 \% ; P=0.01)$ and $\mathrm{EE}(80.0$ vs. $62.6 \% ; P<0.01)$ was greater compared with the CON diet. The digestibility of $\mathrm{OM}$ and $\mathrm{CP}$ was not different between cows fed the LG and CON diets.

\section{Chewing Activity and Sorting Behavior}

Eating, ruminating, and total chewing time $(\mathrm{min} / \mathrm{d})$ were not affected by treatment (Table 4 ). However, cows fed the LF diet tended to spend less time eating (9.8 vs. $13.7 \mathrm{~min} / \mathrm{kg}$ of DMI; $P=0.07)$ and had less ruminating time (20.0 vs. $25.4 \mathrm{~min} / \mathrm{kg}$ of DMI; $P=0.01)$ and chewing time (29.7 vs. $39.1 \mathrm{~min} / \mathrm{kg}$ of DMI; $P<0.01$ ) compared with those fed the CON diet. Similarly, cows fed the LG diet had shorter eating time (9.5 vs. 13.7 $\mathrm{min} / \mathrm{kg}$ of DMI; $P=0.05)$ and total chewing time (31.6 vs.39.1 $\mathrm{min} / \mathrm{kg}$ of DMI; $P=0.01$ ) and tended to have shorter ruminating time (22.1 vs. $25.4 \mathrm{~min} / \mathrm{kg}$ of DMI; $P=0.09)$ than cows fed the CON diet. For cows fed the LF diet, total chewing time per unit of NDF intake was also lower (91.0 vs. $110.3 \mathrm{~min} / \mathrm{kg}$ of NDF intake; $P=$ $0.02)$ than those fed the CON diet. When barley grain was partially replaced by DDGS, eating (25.1 vs. 38.6 $\mathrm{min} / \mathrm{kg}$ of NDF intake; $P=0.04$ ), ruminating (58.4 vs. $71.7 \mathrm{~min} / \mathrm{kg}$ of NDF intake; $P=0.02$ ), and total chewing (83.5 vs. $110.3 \mathrm{~min} / \mathrm{kg} \mathrm{NDF}$ intake; $P<0.01$ ) time were reduced.

For particles retained on the 19-mm sieve, the sorting index was $<100(P<0.05)$ for all 3 diets, indicating that all animals sorted against long particles (Table 4). However, cows fed the LF diet sorted against long particles to a lesser extent than those fed the CON diet (91.0 vs. $80.5 ; P=0.05)$.

\section{Rumen $\mathrm{pH}$ and Rumen Fermentation}

The daily mean, minimum, maximum rumen $\mathrm{pH}$, duration of $\mathrm{pH}<5.8$ or $\mathrm{pH}<5.5$, and the area below $\mathrm{pH} 5.8$ or 5.5 were not affected by feeding the LF diet (Table 5). However, cows fed the LG diet tended to have higher minimum (5.85 vs. $5.50 ; P=0.10)$ and maximum (7.00 vs. $6.86 ; P=0.07)$ rumen $\mathrm{pH}$ than cows fed the CON diet. For cows fed the LG diet, the daily minimum rumen $\mathrm{pH}$ was 5.85 , but the duration and area below $\mathrm{pH} 5.8$ or 5.5 were greater than zero, which was caused by variations among animals. Total VFA concentration, the molar proportions of individual VFA, and the concentration of rumen $\mathrm{NH}_{3}-\mathrm{N}$ did not differ among treatments. 
Table 3. Effects of partially replacing barley silage or barley grain with dried distillers grains with solubles in diets for lactating cows on feed intake and apparent total-tract digestibility

\begin{tabular}{|c|c|c|c|c|c|c|}
\hline \multirow[b]{2}{*}{ Item } & \multicolumn{3}{|c|}{$\operatorname{Diet}^{1}$} & \multirow[b]{2}{*}{ SEM } & \multicolumn{2}{|c|}{$P$-value } \\
\hline & $\begin{array}{c}\mathrm{CON} \\
(\mathrm{n}=6)\end{array}$ & $\begin{array}{c}\mathrm{LF} \\
(\mathrm{n}=6)\end{array}$ & $\begin{array}{c}\mathrm{LG} \\
(\mathrm{n}=6)\end{array}$ & & CON vs. LF & CON vs. LG \\
\hline \multicolumn{7}{|l|}{ Intake, $\mathrm{kg} / \mathrm{d}$} \\
\hline DM & 22.4 & 26.0 & 23.7 & 0.5 & 0.01 & 0.11 \\
\hline $\mathrm{OM}$ & 20.4 & 23.5 & 21.6 & 0.4 & $<0.01$ & 0.07 \\
\hline $\mathrm{CP}$ & 4.2 & 5.1 & 4.5 & 0.1 & 0.01 & 0.19 \\
\hline NDF & 8.0 & 8.5 & 8.9 & 0.2 & 0.09 & 0.01 \\
\hline Starch & 6.5 & 6.3 & 4.5 & 0.1 & 0.32 & $<0.01$ \\
\hline Ether extract & 0.4 & 0.9 & 0.9 & 0.03 & $<0.01$ & $<0.01$ \\
\hline Solid passage rate, $\% / \mathrm{h}$ & 3.6 & 2.3 & 2.9 & 0.5 & 0.08 & 0.30 \\
\hline \multicolumn{7}{|l|}{ Digestibility, $\%$} \\
\hline DM & 65.6 & 67.7 & 63.3 & 0.6 & 0.03 & 0.02 \\
\hline $\mathrm{OM}$ & 69.3 & 71.0 & 68.5 & 0.5 & 0.05 & 0.28 \\
\hline $\mathrm{CP}$ & 68.3 & 70.6 & 66.7 & 0.6 & 0.03 & 0.11 \\
\hline NDF & 52.6 & 53.2 & 55.1 & 0.6 & 0.50 & 0.01 \\
\hline Starch & 96.7 & 95.3 & 94.1 & 0.2 & 0.01 & $<0.01$ \\
\hline Ether extract & 62.6 & 78.4 & 80.0 & 1.8 & $<0.01$ & $<0.01$ \\
\hline
\end{tabular}

${ }^{1} \mathrm{CON}=$ control; $\mathrm{LF}=$ low forage $\mathrm{LG}=$ low grain.

\section{Plasma Metabolites and Milk Production}

Plasma concentrations of urea and glucose were not affected by treatment, averaging 12.5 and $64.3 \mathrm{mg} / \mathrm{dL}$, respectively (Table 6). The concentration of insulin tended (14.5 vs. $11.7 \mu \mathrm{IU} / \mathrm{mL} ; P=0.10)$ to be higher for cows fed the LF diet compared with those fed the CON diet, whereas it was not affected by feeding the LG diet.

Milk yield was higher $(36.4$ vs. $33.0 \mathrm{~kg} / \mathrm{d} ; P=0.01)$ for cows fed the LF diet than for those fed the CON diet
(Table 7). Cows fed the LF diet had greater (35.1 vs. $33.1 \mathrm{~kg} / \mathrm{d} ; P<0.01)$ ECM yield compared with those fed the CON diet. The yields of milk protein $(1.18$ vs. $1.05 \mathrm{~kg} / \mathrm{d} ; P=0.01)$ and lactose (1.63 vs. $1.46 \mathrm{~kg} / \mathrm{d}$; $P=0.01)$ were also greater for cows fed the LF diet compared with those fed the CON diet. Milk protein concentration tended to be higher (3.31 vs. $3.26 \%$; $P$ $=0.07$ ) for cows fed the LF diet than for those fed the CON diet. There were no differences in milk yield or milk composition between cows fed the LG and CON diets, but cows fed the LG diet had greater (35.1 vs.

Table 4. Effects of partially replacing barley silage or barley grain with dried distillers grains with solubles in diets for lactating cows on chewing activity and sorting behavior

\begin{tabular}{|c|c|c|c|c|c|c|}
\hline \multirow[b]{2}{*}{ Item } & \multicolumn{3}{|c|}{ Diet $^{1}$} & \multirow[b]{2}{*}{ SEM } & \multicolumn{2}{|c|}{$P$-value } \\
\hline & $\begin{array}{c}\mathrm{CON} \\
(\mathrm{n}=6)\end{array}$ & $\begin{array}{c}\mathrm{LF} \\
(\mathrm{n}=6)\end{array}$ & $\begin{array}{c}\mathrm{LG} \\
(\mathrm{n}=6)\end{array}$ & & CON vs. LF & CON vs. LG \\
\hline \multicolumn{7}{|l|}{ Time, $\min / \mathrm{d}$} \\
\hline Eating & 303 & 250 & 226 & 37 & 0.30 & 0.15 \\
\hline Ruminating & 563 & 518 & 518 & 23 & 0.20 & 0.21 \\
\hline Total chewing ${ }^{2}$ & 866 & 768 & 744 & 41 & 0.13 & 0.07 \\
\hline \multicolumn{7}{|c|}{ Time, $\min / \mathrm{kg}$ of DMI } \\
\hline Eating & 13.7 & 9.8 & 9.5 & 1.3 & 0.07 & 0.05 \\
\hline Ruminating & 25.4 & 20.0 & 22.1 & 1.2 & 0.01 & 0.09 \\
\hline Total chewing & 39.1 & 29.7 & 31.6 & 1.7 & $<0.01$ & 0.01 \\
\hline \multicolumn{7}{|c|}{ Time, min $/ \mathrm{kg}$ of NDF intake } \\
\hline Eating & 38.6 & 29.7 & 25.1 & 3.8 & 0.14 & 0.04 \\
\hline Ruminating & 71.7 & 61.1 & 58.4 & 3.4 & 0.06 & 0.02 \\
\hline Total chewing & 110.3 & 91.0 & 83.5 & 4.7 & 0.02 & $<0.01$ \\
\hline \multicolumn{7}{|l|}{ Sorting index ${ }^{3}$} \\
\hline$>19 \mathrm{~mm}$ & 80.5 & 91.0 & 85.0 & 3.2 & 0.05 & 0.35 \\
\hline $19-8 \mathrm{~mm}$ & 101.5 & 103.0 & 103.2 & 0.8 & 0.21 & 0.17 \\
\hline$<8 \mathrm{~mm}$ & 101.0 & 99.5 & 99.0 & 0.7 & 0.16 & 0.07 \\
\hline
\end{tabular}

${ }^{1} \mathrm{CON}=$ control; $\mathrm{LF}=$ low forage $\mathrm{LG}=$ low grain.

${ }^{2}$ Sum of time on eating and ruminating time.

${ }^{3}$ Sorting index $>100$ indicates sorting for particles and $<100$ indicates sorting against particles (Leonardi and Armentano, 2003). 
Table 5. Effects of partially replacing barley silage or barley grain with dried distillers grains with solubles in diets for lactating cows on rumen $\mathrm{pH}$ and rumen fermentation

\begin{tabular}{|c|c|c|c|c|c|c|}
\hline \multirow[b]{2}{*}{ Item } & \multicolumn{3}{|c|}{ Diet $^{1}$} & \multirow[b]{2}{*}{ SEM } & \multicolumn{2}{|c|}{$P$-value } \\
\hline & $\begin{array}{c}\mathrm{CON} \\
(\mathrm{n}=6)\end{array}$ & $\begin{array}{c}\mathrm{LF} \\
(\mathrm{n}=6)\end{array}$ & $\begin{array}{c}\mathrm{LG} \\
(\mathrm{n}=6)\end{array}$ & & $\mathrm{CON}$ vs. LF & CON vs. LG \\
\hline \multicolumn{7}{|l|}{ Rumen pH } \\
\hline Mean & 6.21 & 6.17 & 6.39 & 0.08 & 0.72 & 0.13 \\
\hline Minimum & 5.50 & 5.51 & 5.85 & 0.13 & 0.96 & 0.10 \\
\hline Maximum & 6.86 & 6.78 & 7.00 & 0.05 & 0.32 & 0.07 \\
\hline \multicolumn{7}{|l|}{ Area, $\mathrm{pH} \times \mathrm{h} / \mathrm{d}$} \\
\hline $\mathrm{pH}<5.8$ & 2.1 & 3.3 & 1.5 & 0.9 & 0.40 & 0.66 \\
\hline $\mathrm{pH}<5.5$ & 0.3 & 0.8 & 0.4 & 0.3 & 0.31 & 0.73 \\
\hline \multicolumn{7}{|l|}{ Duration, h/d } \\
\hline $\mathrm{pH}<5.8$ & 3.9 & 4.7 & 1.8 & 1.1 & 0.64 & 0.21 \\
\hline $\mathrm{pH}<5.5$ & 0.8 & 1.3 & 0.8 & 0.5 & 0.45 & 0.91 \\
\hline Total VFA, $\mathrm{m} M$ & 130.7 & 131.9 & 136.8 & 4.6 & 0.86 & 0.38 \\
\hline \multicolumn{7}{|c|}{ Molar proportion, mol/100 mol } \\
\hline Acetate & 60.2 & 60.6 & 60.5 & 1.4 & 0.81 & 0.88 \\
\hline Propionate & 24.1 & 22.4 & 23.1 & 2.1 & 0.58 & 0.74 \\
\hline Isobutyrate & 0.95 & 0.95 & 0.89 & 0.04 & 0.93 & 0.35 \\
\hline Butyrate & 10.8 & 11.7 & 11.6 & 0.7 & 0.37 & 0.43 \\
\hline Isovalerate & 1.25 & 1.44 & 1.25 & 0.13 & 0.33 & 0.98 \\
\hline Valerate & 2.24 & 2.20 & 2.11 & 0.16 & 0.85 & 0.57 \\
\hline Rumen $\mathrm{NH}_{3}-\mathrm{N}, \mathrm{mg} / \mathrm{dL}$ & 13.4 & 14.5 & 14.2 & 0.7 & 0.29 & 0.47 \\
\hline
\end{tabular}

${ }^{1} \mathrm{CON}=$ control; $\mathrm{LF}=$ low forage; $\mathrm{LG}=$ low grain.

$33.1 \mathrm{~kg} / \mathrm{d} ; P<0.01)$ ECM yield compared with those fed the CON diet. Feed efficiency expressed as the ratio of milk yield to DMI was not affected by treatment, but when expressed as the ratio of ECM to DMI (1.35 vs. $1.46 ; P=0.01)$ or of ECM to $\mathrm{NE}_{\mathrm{L}}$ intake $(0.80$ vs. $0.92 ; P<0.01)$, feed efficiency was lower for cows fed the LF diet. Changes in BW and BCS were not affected by treatment.

Concentration of $\mathrm{C} 16$ in milk fat was lower for cows fed the LF diet compared with those fed the CON diet (30.1 vs. $32.9 \% ; P=0.01$; Table 8 ). Feeding the LF diet tended to decrease ( 68.7 vs. $71.2 \% ; P=0.10)$ the proportion of saturated fatty acids and to increase (31.3 vs. $28.8 \%$; $P=0.10$ ) the proportion of unsaturated fatty acids (UFA) compared with the CON diet. Cows fed the LG diet had greater concentrations of long-chain fatty acids (41.3 vs. $35.6 \% ; P=0.01)$ and lower concentration of C16 (31.4 vs. $35.5 \% ; P<0.01$ ), and tended to have lower concentrations of short- and medium-chain fatty acids ( 24.1 vs. $26.0 \% ; P=0.08$ ) compared with those fed the CON diet. In addition, the proportion of saturated fatty acids in milk fat was decreased ( 68.0 vs. $71.2 \% ; P=0.04$ ), whereas the proportion of UFA in milk was increased by feeding the LG $\operatorname{diet}(32.0$ vs. $28.8 \% ; P=0.04)$.

\section{Energy Balance}

Compared with that of the $\mathrm{CON}$ diet, $\mathrm{NE}_{\mathrm{L}}$ intake was increased ( 44.3 vs. $35.5 \mathrm{Mcal} / \mathrm{d} ; P<0.01$ ) by feeding the LF diet but was not affected by the LG diet (Table $9)$. Energy output as milk production was greater $(P$ $=0.01)$ for both LF $(23.4 \mathrm{Mcal} / \mathrm{d})$ and LG diets $(23.5$ $\mathrm{Mcal} / \mathrm{d})$ relative to the $\mathrm{CON} \operatorname{diet}(22.1 \mathrm{Mcal} / \mathrm{d})$. The resulting net energy balance was higher (10.1 vs. 2.67 $\mathrm{Mcal} / \mathrm{d} ; P<0.01$ ) for cows fed the LF diet compared with those fed the CON diet but did not differ between cows fed the CON and LG diets.

Table 6. Effects of partially replacing barley silage or barley grain with dried distillers grains with solubles in diets for lactating cows on plasma metabolite concentrations

\begin{tabular}{|c|c|c|c|c|c|c|}
\hline \multirow[b]{2}{*}{ Item } & \multicolumn{3}{|c|}{ Diet $^{1}$} & \multirow[b]{2}{*}{ SEM } & \multicolumn{2}{|c|}{$P$-value } \\
\hline & $\begin{array}{c}\mathrm{CON} \\
(\mathrm{n}=6)\end{array}$ & $\begin{array}{c}\mathrm{LF} \\
(\mathrm{n}=6)\end{array}$ & $\begin{array}{c}\mathrm{LG} \\
(\mathrm{n}=6)\end{array}$ & & CON vs. LF & CON vs. LG \\
\hline Urea-N, mg/dL & 11.8 & 12.6 & 13.0 & 0.9 & 0.54 & 0.36 \\
\hline Glucose, mg/dL & 63.2 & 65.7 & 64.0 & 1.4 & 0.23 & 0.67 \\
\hline Insulin, $\mu \mathrm{IU} / \mathrm{mL}$ & 11.7 & 14.5 & 10.2 & 1.0 & 0.10 & 0.32 \\
\hline
\end{tabular}

${ }^{1} \mathrm{CON}=$ control; $\mathrm{LF}=$ low forage $\mathrm{LG}=$ low grain. 
Table 7. Effects of partially replacing barley silage or barley grain with dried distillers grains with solubles in diets for lactating cows on milk production and milk composition

\begin{tabular}{|c|c|c|c|c|c|c|}
\hline \multirow[b]{2}{*}{ Item } & \multicolumn{3}{|c|}{$\operatorname{Diet}^{1}$} & \multirow[b]{2}{*}{ SEM } & \multicolumn{2}{|c|}{$P$-value } \\
\hline & $\begin{array}{c}\mathrm{CON} \\
(\mathrm{n}=6)\end{array}$ & $\begin{array}{c}\mathrm{LF} \\
(\mathrm{n}=6)\end{array}$ & $\begin{array}{c}\mathrm{LG} \\
(\mathrm{n}=6)\end{array}$ & & CON vs. LF & CON vs. LG \\
\hline \multicolumn{7}{|l|}{ Yield, $\mathrm{kg} / \mathrm{d}$} \\
\hline Milk & 33.0 & 36.4 & 34.7 & 0.7 & 0.01 & 0.14 \\
\hline $\mathrm{ECM}^{2}$ & 33.1 & 35.1 & 35.1 & 0.4 & $<0.01$ & $<0.01$ \\
\hline Fat & 1.14 & 1.14 & 1.22 & 0.04 & 1.00 & 0.14 \\
\hline $\mathrm{CP}$ & 1.05 & 1.18 & 1.10 & 0.02 & 0.01 & 0.14 \\
\hline Lactose & 1.46 & 1.63 & 1.55 & 0.04 & 0.01 & 0.13 \\
\hline \multicolumn{7}{|l|}{ Composition } \\
\hline Fat, $\%$ & 3.53 & 3.29 & 3.61 & 0.11 & 0.14 & 0.65 \\
\hline $\mathrm{CP}, \%$ & 3.26 & 3.31 & 3.25 & 0.02 & 0.07 & 0.66 \\
\hline Lactose, $\%$ & 4.34 & 4.42 & 4.39 & 0.04 & 0.21 & 0.37 \\
\hline MUN, mg/dL & 13.9 & 14.6 & 15.4 & 0.9 & 0.59 & 0.25 \\
\hline \multicolumn{7}{|l|}{ Feed efficiency } \\
\hline Milk yield/DMI & 1.45 & 1.39 & 1.47 & 0.03 & 0.25 & 0.70 \\
\hline ECM/DMI & 1.46 & 1.35 & 1.49 & 0.02 & 0.01 & 0.42 \\
\hline $\mathrm{ECM} / \mathrm{NE}_{\mathrm{L}}$ intake & 0.92 & 0.80 & 0.95 & 0.02 & $<0.01$ & 0.21 \\
\hline $\mathrm{BW}, \mathrm{kg}$ & 690 & 691 & 690 & 4 & 0.84 & 0.20 \\
\hline BW change, kg/d & 0.56 & 0.33 & 0.66 & 0.38 & 0.68 & 0.85 \\
\hline BCS change, $/ 21 \mathrm{~d}$ & 0.15 & 0.15 & 0.10 & 0.15 & 1.00 & 0.48 \\
\hline
\end{tabular}

\section{DISCUSSION}

Previous research has indicated that the response of cows to feeding dietary high-fiber byproducts is largely affected by the type of carbohydrate source (forage or grain) being replaced (Ipharraguerre and Clark, 2003). As a nonforage fiber source (NFFS), DDGS contains highly digestible NDF (Getachew et al., 2004), thus the feeding value of DDGS as a replacement of either forage or grain is of interest. Partial replacement of barley silage with wet distillers grains increased milk yield but decreased milk fat concentration (Penner et al., 2009). However, in their study, the dietary allocation of barley grain was increased by $4 \%$ in the diet containing wet distillers grains. Therefore, the treatment effect on milk production is confounded by the different dietary allocation of barley grain. Grings et al. (1992) linearly increased the dietary inclusion of DDGS $(0,10,20$, and $30 \%$ ) by replacing corn grain, but diets containing DDGS also linearly increased dietary CP concentration $(13.9,16.0,18.1$, and $20.3 \%)$. As such, effects of feeding DDGS on animal responses were confounded by different dietary CP concentrations. To increase our understanding of DDGS as an energy source, the current study was undertaken to evaluate effects of DDGS as a partial replacement for barley silage or barley grain in diets for lactating dairy cows. The experimental diets were formulated to be isonitrogenous using feed ingredients other than forage or grain to minimize confounding effects of different dietary CP concentration.

\section{DDGS as a Partial Replacement of Barley Silage}

In this study, barley silage was replaced by DDGS at $20 \%$ of dietary DM without the change in dietary allocation of barley grain to minimize the confounding effects of diet fermentability on animal responses. Feeding the LF diet increased milk yield by $3.4 \mathrm{~kg} / \mathrm{d}$. The higher milk yield is likely attributed to the greater DMI $(+3.6 \mathrm{~kg} / \mathrm{d})$ and $\mathrm{NE}_{\mathrm{L}}$ intake $(+8.8 \mathrm{Mcal} / \mathrm{d})$ for cows fed the LF diet compared with those fed the CON diet. A tendency for greater plasma insulin concentration for the $\mathrm{LF}$ treatment $(+2.8 \mu \mathrm{IU} / \mathrm{mL})$ also supports that cows fed the LF diet improved their energy status compared with those fed the CON diet. Penner et al. (2009) also observed greater milk yield by replacing barley silage with wet distillers grains at $10 \%$ of dietary DM and attributed the higher milk yield to a possible increase in metabolizable protein flow to the small intestine. This may also partially explain the higher milk yield in the current study as apparent total-tract digestibility of CP was greater for cows fed the LF diet compared with the CON diet.

The greater DMI for cows fed the LF diet as observed in our study is in agreement with Janicek et al. (2008), in which DDGS was used as a partial replacement for corn silage and concentrates at 10,20, and $30 \%$ of dietary DM. In that study, cows linearly increased DMI as the dietary allocation of DDGS increased. Allen and Grant (2000) suggested that the inclusion of NFFS as a partial replacement for forage reduced dietary particle 
Table 8. Effects of partially replacing barley silage or barley grain with dried distillers grains with solubles in diets for lactating cows on milk fatty acids (FA) profile

\begin{tabular}{|c|c|c|c|c|c|c|}
\hline \multirow[b]{2}{*}{$\mathrm{FA}, \mathrm{g} / 100 \mathrm{~g}$ of total FA } & \multicolumn{3}{|c|}{$\operatorname{Diet}^{1}$} & \multirow[b]{2}{*}{ SEM } & \multicolumn{2}{|c|}{$P$-value } \\
\hline & $\begin{array}{c}\mathrm{CON} \\
(\mathrm{n}=6)\end{array}$ & $\begin{array}{c}\mathrm{LF} \\
(\mathrm{n}=6)\end{array}$ & $\begin{array}{c}\mathrm{LG} \\
(\mathrm{n}=6)\end{array}$ & & CON vs. LF & CON vs. LG \\
\hline C4:0 & 0.44 & 0.38 & 0.42 & 0.02 & 0.06 & 0.51 \\
\hline C6:0 & 1.21 & 1.14 & 1.23 & 0.07 & 0.35 & 0.87 \\
\hline C7:0 & 0.07 & 0.09 & 0.06 & 0.01 & 0.26 & 0.42 \\
\hline C8:0 & 1.16 & 1.12 & 1.13 & 0.05 & 0.61 & 0.64 \\
\hline C9:0 & 0.09 & 0.11 & 0.08 & 0.01 & 0.09 & 0.06 \\
\hline C10:0 & 2.96 & 3.09 & 2.83 & 0.15 & 0.54 & 0.56 \\
\hline C11:0 & 0.39 & 0.42 & 0.34 & 0.01 & 0.10 & 0.01 \\
\hline C12:0 & 3.94 & 4.28 & 3.67 & 0.15 & 0.14 & 0.24 \\
\hline $\mathrm{C} 14: 0$ & 12.9 & 12.8 & 11.9 & 0.3 & 0.97 & 0.07 \\
\hline $\mathrm{C} 14: 1$ & 1.15 & 1.09 & 0.89 & 0.13 & 0.76 & 0.20 \\
\hline C15:0 & 1.44 & 1.79 & 1.33 & 0.09 & 0.03 & 0.43 \\
\hline C16:0 & 32.9 & 30.1 & 29.2 & 0.6 & 0.01 & 0.01 \\
\hline C16:1 & 2.53 & 2.58 & 2.2 & 0.1 & 0.72 & 0.04 \\
\hline C17:1 & 0.24 & 0.24 & 0.20 & 0.02 & 0.82 & 0.05 \\
\hline C18:0 & 8.76 & 8.38 & 10.97 & 0.35 & 0.46 & 0.01 \\
\hline C18:1 trans & 1.71 & 3.47 & 2.58 & 0.65 & 0.09 & 0.37 \\
\hline $\mathrm{C} 18: 1$ cis & 20.5 & 20.1 & 22.5 & 0.85 & 0.72 & 0.14 \\
\hline C18:1 & 22.2 & 23.5 & 25.1 & 0.7 & 0.23 & 0.23 \\
\hline C19:0 & 0.15 & 0.18 & 0.18 & 0.01 & 0.12 & 0.12 \\
\hline C18:2 & 2.68 & 3.48 & 3.10 & 0.21 & 0.03 & 0.20 \\
\hline C20:0 & 0.08 & 0.11 & 0.12 & 0.02 & 0.32 & 0.22 \\
\hline $\mathrm{C} 20: 1$ & 0.20 & 0.18 & 0.21 & 0.02 & 0.47 & 0.47 \\
\hline C18:3 & 0.39 & 0.36 & 0.36 & 0.01 & 0.06 & 0.03 \\
\hline Conjugated linoleic acid, 9/11 & 0.50 & 0.73 & 0.73 & 0.09 & 0.12 & 0.11 \\
\hline $\mathrm{C} 22: 0$ & 0.02 & 0.01 & 0.02 & 0.01 & 0.36 & 0.64 \\
\hline C20:3 n6 & 0.15 & 0.19 & 0.17 & 0.01 & 0.04 & 0.22 \\
\hline $\mathrm{C} 20: 4$ & 0.17 & 0.18 & 0.16 & 0.01 & 0.30 & 0.48 \\
\hline Short and medium $(\mathrm{C}<16)$ & 26.0 & 26.7 & 24.1 & 0.6 & 0.44 & 0.08 \\
\hline $\mathrm{C} 16^{2}$ & 35.5 & 32.7 & 31.4 & 0.6 & 0.01 & $<0.01$ \\
\hline Long $(\mathrm{C}>16)$ & 35.6 & 37.6 & 41.3 & 1.0 & 0.18 & 0.01 \\
\hline $\mathrm{SFA}^{3}(\mathrm{C}-10)$ & 71.2 & 68.7 & 68.0 & 0.9 & 0.10 & 0.04 \\
\hline $\mathrm{UFA}^{3}$ & 28.8 & 31.3 & 32.0 & 0.9 & 0.10 & 0.04 \\
\hline
\end{tabular}

size and increased DMI because of a faster passage rate. In contrast, we observed that cows fed the LF diet had higher DMI but tended to have a slower passage rate compared with those fed the CON diet. These discrepancies suggested that the greater DMI could not be attributed to faster passage rate and reduced physical fill in our study. Greater DMI associated with faster passage rates would generally decrease digestibility of nutrients (Tyrrell and Moe, 1975; Colucci et al., 1982), but we observed greater total-tract digestibility of most nutrients for cows fed the LF diet.

Although a partial replacement of barley silage with DDGS decreased dietary forage NDF content, neither concentration nor yield of milk fat were affected. Past studies demonstrated that cows fed a low forage diet (Yang and Beauchemin, 2007) or a diet with shorter particle size (Krause and Combs, 2003) showed a reduced milk fat concentration. Cows fed the LF diet had lower chewing time ( $\mathrm{min} / \mathrm{kg}$ of DMI) compared with those fed the CON diet, which is in agreement with other studies using NFFS as a partial replacement of forage fiber (Clark and Armentano, 1997; Allen and Grant, 2000; Penner et al., 2009). However, regardless of the reduced chewing time, rumen $\mathrm{pH}$ was not different between cows fed the LF and CON diets. This is possibly because rumen $\mathrm{pH}$ is determined not only by dietary forage NDF concentration, but also by other factors such as fermentability of diets (Yang and Beauchemin, 2009). Although forage NDF was $14.6 \%$ for the LF diet, the dietary NFC concentration was $34.8 \%$. According to NRC (2001), dietary forage NDF concentration can be decreased to $15 \%$ if dietary NFC concentration is $36 \%$ or less.

\section{DDGS as a Partial Replacement of Barley Grain}

Using DDGS as a partial replacement for barley grain did not affect milk yield despite a 10-percentage- 
Table 9. Effects of partially replacing barley silage or barley grain with dried distillers grains with solubles in diets for lactating cows on calculated energy intake, output, and balance

\begin{tabular}{|c|c|c|c|c|c|c|}
\hline \multirow[b]{2}{*}{ Item } & \multicolumn{3}{|c|}{ Diet $^{1}$} & \multirow[b]{2}{*}{ SEM } & \multicolumn{2}{|c|}{$P$-value } \\
\hline & $\begin{array}{c}\mathrm{CON} \\
(\mathrm{n}=6)\end{array}$ & $\begin{array}{c}\mathrm{LF} \\
(\mathrm{n}=6)\end{array}$ & $\begin{array}{c}\mathrm{LG} \\
(\mathrm{n}=6)\end{array}$ & & CON vs. LF & CON vs. LG \\
\hline Dietary $\mathrm{NE}_{\mathrm{L}}^{2}, \mathrm{Mcal} / \mathrm{kg}$ & 1.58 & 1.71 & 1.58 & 0.04 & 0.03 & 0.90 \\
\hline $\mathrm{NE}_{\mathrm{L}}$ intake, Mcal/d & 35.5 & 44.3 & 37.3 & 0.9 & $<0.01$ & 0.22 \\
\hline $\mathrm{NE}_{\mathrm{L}}$ output, Mcal/d & 22.1 & 23.4 & 23.5 & 0.3 & 0.01 & 0.01 \\
\hline $\mathrm{NE}_{\mathrm{M}}$ output, Mcal/d & 10.8 & 10.8 & 10.8 & 0.04 & 0.84 & 0.20 \\
\hline Total NE output, Mcal/d & 32.8 & 34.2 & 34.3 & 0.3 & 0.01 & 0.01 \\
\hline NE balance, Mcal/d & 2.67 & 10.1 & 2.96 & 0.74 & $<0.01$ & 0.79 \\
\hline
\end{tabular}

unit reduction in the dietary starch concentration. This result indicates that the DDGS used in the current study could be used as an alternative energy source to partially replace barley grain in diets for lactating dairy cows. The high energy content of DDGS may be attributed to the highly digestible NDF and the high EE content. Nuez Ortin and $\mathrm{Yu}(2009)$ reported the 48-h in situ NDF digestibility of corn- and wheat-DDGS to be $79.4 \%$ and $63.5 \%$, respectively. In addition, EE intake and total digestibility of EE were higher for cows fed the LG diet than for those fed the CON diet. Collectively, these factors contributed to greater $\mathrm{NE}_{\mathrm{L}}$ intake and milk energy output for cows fed the LG diet relative to the CON diet.

Milk fat yield or concentration was not affected by the LG treatment in the present study. Past studies showed that milk fat concentration was not affected (Boddugari et al., 2001; Voelker and Allen, 2003a; Leonardi et al., 2005) or increased (Mansfield et al., 1994; Ipharraguerre et al., 2002) without affecting milk yield when cows were fed NFFS in place of grain. Milk fat production can be affected by the concentration of dietary UFA (Griinari et al., 1998). Fat in corn DDGS was high in concentrations of C18:1 and C18:2 (Sasikala-Appukuttan et al., 2008), and the inclusion of $20 \%$ DDGS in the present study likely increased the dietary concentrations of long-chain fatty acids and UFA. Feeding a high UFA diet, particularly in combination with low rumen $\mathrm{pH}$, alters the biohydrogenation pathway in the rumen and allows for the accumulation of intermediates (Griinari et al., 1998) such as trans-10, cis-12 conjugated linoleic acid, which inhibits de novo fatty acid synthesis in the mammary gland (Peterson et al., 2003). Although cows fed the LG diet tended to have increased daily minimum and maximum rumen $\mathrm{pH}$ compared with those fed the CON diet, they had lower concentrations of $\mathrm{C} 16$ and tended to have lower concentrations of short- and medium-chain fatty acids. However, the concentration of long-chain fatty acids in milk was higher for the LG treatment compared with the CON, reflecting the greater supply of dietary long-chain fatty acids with the substitution of DDGS for barley grain. The reduction in short- and mediumchain fatty acids might have been compensated for by the increased long-chain fatty acids absorbed from dietary source in the present study and resulted in no difference in milk fat concentration between cows fed the LG and CON diets. Similar changes in milk fatty acid profile were observed in other studies (Schingoethe et al., 1999; Leonardi et al., 2005).

We hypothesized that feeding the LG diet would increase rumen $\mathrm{pH}$ because the starch concentration was lower for the LG compared with the CON diet. Cows fed the LG diet tended to have higher rumen $\mathrm{pH}$ compared with those fed the CON diet possibly because diet fermentability was lower for the LG diet. Starch content was lower for DDGS than for grain because the starch is almost completely removed by ethanol production (Nuez Ortin and $\mathrm{Yu}, 2009$ ). We also expected that cows fed the LG diet would maintain chewing activity because dietary forage NDF content and the particle size distribution were similar between the LG and CON diets. However, cows fed the LG diet had lower chewing time ( $\mathrm{min} / \mathrm{kg}$ of DMI) compared with cows on the CON diet. Although the concentrates used for LG and CON diets were further separated by using the additional 1.18-mm aperture sieve (Kononoff et al., 2003), the LG concentrate had $76.9 \%$ particles retained on $1.18-\mathrm{mm}$ sieve, whereas the CON concentrate had $69.5 \%$. Therefore, it is not clear why feeding the LG diet decreased chewing time compared with the CON diet. It has been suggested that the use of DDGS as partial replacement of grain may reduce the risk of rumen acidosis in high-producing dairy cows (Stone, 2004). However, rumen $\mathrm{pH}$ is also affected by chewing activity as it stimulates the secretion of saliva to buffer fermentation acids produced in the rumen (Mertens, 1997). Beliveau and McKinnon (2009) reported that 
the substitution of wheat DDGS for barley grain had no effect on daily mean rumen $\mathrm{pH}$ in finishing beef cattle. Therefore, effects of feeding DDGS as a partial replacement of grain on rumen $\mathrm{pH}$ warrants further investigation.

\section{Effects of Feeding DDGS on Nutrient Digestibility}

The higher digestibility of NDF for cows fed the LG diet is in agreement with Birkelo et al. (2004) who reported that the apparent total-tract NDF digestibility increased (60.6 vs. $49.2 \%$ ) when cows were fed wet distillers grains in place of corn grain and soybean meal. The greater NDF digestibility may be attributed to the tendency of higher rumen $\mathrm{pH}$ for cows fed the LG diet that contained less starch and NFC than the CON diet. Despite of the greater NDF digestibility, DM digestibility was decreased by feeding the LG diet and this may be partially attributed to the lower starch digestibility as well as lower dietary starch content. Diets containing DDGS (LF and LG diets) decreased starch digestibility, and this might have resulted from the low amylolytic activity in the rumen of cows fed low starch diets (Oba and Allen, 2003). The growth of amylolytic bacteria is affected by the dietary starch content (Cotta, 1988). Further, Voelker and Allen (2003b) observed that rumen starch digestibility decreased from 42.2 to $9.7 \%$ when high-moisture corn was replaced by beet pulp at $24 \%$ of dietary DM in diets of lactating dairy cows, but total-tract starch digestibility was not affected because of greater starch digestion in the intestine in their study. The greater fat digestibility for the LF and LG diets is consistent with the finding of Vander Pol et al. (2009): total-tract fat digestibility was increased from 72.5 to $81.0 \%$ when $40 \%$ of corn-based concentrate was replaced by wet distillers grains with solubles. The greater fat digestibility may be also attributed to the higher dietary EE content (Palmquist and Conrad, 1978). The higher EE digestibility for animals fed higher dietary EE content was also reported by Smith et al. (1993). These results indicate that digestibility of nutrients can be affected by inclusion of DDGS in diets.

\section{CONCLUSIONS}

Partial replacement of barley silage with DDGS increased DMI and yields of milk, milk protein, and lactose of lactating dairy cows. Despite the lower dietary forage NDF content, no adverse effects on rumen $\mathrm{pH}$ and rumen fermentation were observed in this study. Partial replacement of barley grain with DDGS tended to increase rumen $\mathrm{pH}$ but did not affect milk yield. In conclusion, DDGS can be used as a partial replacement of forage or grain in diets for lactating dairy cows and considered as an alternative energy source when forage is in short supply or when grain is not available at reasonable costs.

\section{ACKNOWLEDGMENTS}

The authors gratefully acknowledge A. Ruiz-Sanchez, A. Reiz, C. Owen, L. E. McKeown, L. A. Clark, and K. T. Wierenga at the University of Alberta for technical assistance, and the University of Alberta Dairy Unit staff for general animal care. Financial supports from the Alberta Livestock and Meat Agency (Edmonton, AB, Canada), Alberta Milk (Edmonton, AB, Canada), and the Agricultural Bioproducts Innovation Program (Agriculture, Agri-Food Canada, Ottawa, ON, Canada) are gratefully acknowledged.

\section{REFERENCES}

Allen, D. M., and R. J. Grant. 2000. Interactions between forage and wet corn gluten feed as sources of fiber in diets for lactating dairy cows. J. Dairy Sci. 83:322-331.

Anderson, J. L., D. J. Schingoethe, K. F. Kalscheure, and A. R. Hippen. 2006. Evaluation of dried and wet distillers grains included at two concentrations in the diets of lactating dairy cows. J. Dairy Sci. $89: 3133-3142$.

AOAC. 2002. Official Methods of Analysis. 17th ed. AOAC, Gaithersburg, MD.

Beliveau, R. M., and J. J. McKinnon. 2009. Effect of graded levels of wheat-based dried distillers' grains with solubles on rumen fermentation in finishing cattle. Can. J. Anim. Sci. 89:513-520.

Birkelo, C. P., M. J. Brouk, and D. J. Schingoethe. 2004. The energy content of wet corn distillers grains for lactating dairy cows. J. Dairy Sci. 87:1815-1819.

Boddugari, K., R. J. Grant, R. Stock, and M. Lewis. 2001. Maximal replacement of forage and concentrate with a new wet corn milling product for lactating dairy cows. J. Dairy Sci. 84:873-884.

Clark, P. W., and L. E. Armentano. 1993. Effectiveness of neutral detergent fiber in whole cottonseed and dried distillers grains compared with alfalfa haylage. J. Dairy Sci. 76:2644-2650.

Clark, P. W., and L. E. Armentano. 1997. Influence of particle size on the effectiveness of beet pulp fiber. J. Dairy Sci. 80:898-904.

Cochran, R. C., D. C. Adams, J. D. Wallace, and M. L. Galyean. 1986. Predicting digestibility of different diets with internal markers: Evaluation of four potential markers. J. Anim. Sci. 63:14761483.

Colucci, P. E., L. E. Chase, and P. J. Van Soest. 1982. Feed intake, apparent diet digestibility, and rate of particulate passage in dairy cattle. J. Dairy Sci. 65:1445-1456.

Cotta, M. A. 1988. Amylolytic activity of selected species of ruminal bacteria. Appl. Environ. Microbiol. 54:772-776.

Fawcett, J. K., and J. E. Scott. 1960. A rapid and precise method for the determination of urea. J. Clin. Pathol. 13:156-159.

Folch, J., M. Lees, and G. H. S. Stanley. 1957. A simple method for the isolation and purification of total lipids from animal tissues. J. Biol. Chem. 226:477-480.

Getachew, G., P. H. Robinson, E. J. DePeters, and S. J. Taylor 2004. Relationships between chemical composition, dry matter degradation and in vitro gas production of several ruminant feeds. Anim. Feed Sci. Technol. 111:57-71.

Griinari, J. M., D. A. Dwyer, M. A. Mcguire, D. E. Bauman, D. L. Palmquist, and K. V. V. Nurmela. 1998. Trans-octadecenoic acids and milk fat depression in lactating dairy cows. J. Dairy Sci. 81:1251-1261. 
Grings, E. E., R. E. Roffler, and D. P. Deitelhoff. 1992. Responses of dairy cows to additions of distillers dried grains with solubles in alfalfa-based diets. J. Dairy Sci. 75:1946-1953.

Grovum, W. L., and V. J. Williams. 1973. Rate of passage of digesta in sheep. 4. Passage of marker through the alimentary and the biological relevance of rate-constants derived from the changes in concentration of marker in faeces. Br. J. Nutr. 30:313-329.

Ipharraguerre, I. R., and J. H. Clark. 2003. Soyhulls as an alternative feed for lactating dairy cows: A review. J. Dairy Sci. 86:10521073

Ipharraguerre, I. R., R. R. Ipharraguerre, and J. H. Clark. 2002 Performance of lactating dairy cows fed varying amounts of soyhulls as a replacement for corn grain. J. Dairy Sci. 85:2905-2912.

Janicek, B. N., P. J. Kononoff, A. M. Gehman, and P. H. Doane. 2008. The effect of feeding dried distillers grains plus solubles on milk production and excretion of urinary purine derivatives. J. Dairy Sci. 91:3544-3553.

Karkalas, J. 1985. An improved enzymatic method for the determination of native and modified starch. J. Sci. Food Agric. 36:1019-1027.

Khorasani, G. R., E. K. Okine, and J. J. Kennelly. 1996. Forage source alters nutrient supply to the intestine without influencing milk yield. J. Dairy Sci. 79:862-872.

Kleinschmit, D. H., D. J. Schingoethe, K. F. Kalscheur, and A. R. Hippen. 2006. Evaluation of various sources of corn dried distillers grains plus solubles for lactating dairy cattle. J. Dairy Sci. 89:4784-4794.

Kononoff, P. J., A. J. Heinrichs, and D. R. Buckmaster. 2003. Modification of the Penn State forage and total mixed ration particle separator and the effects of moisture content on its measurements. 2003. J. Dairy Sci. 86:1858-1863.

Krause, K. M., and D. K. Combs. 2003. Effects of forage particle size, forage source, and grain fermentability on performance and ruminal $\mathrm{pH}$ in midlactation cows. J. Dairy Sci. 86:1382-1397.

Lammers, B. P., D. R. Buckmaster, and A. J. Heinrichs. 1996. A simple method for the analysis of particle sizes of forage and total mixed rations. J. Dairy Sci. 79:922-928.

Leonardi, C., and L. E. Armentano. 2003. Effect of quantity, quality, and length of alfalfa hay on selective consumption by dairy cows. J. Dairy Sci. 86:557-564.

Leonardi, C., S. Bertics, and L. E. Armentano. 2005. Effect of increasing oil from distillers grains or corn oil on lactation performance. J. Dairy Sci. 88:2820-2827.

Mansfield, H. R., M. D. Stern, and D. E. Otterby. 1994. Effects of beet pulp and animal by-products on milk yield and in vitro fermentation by rumen microorganisms. J. Dairy Sci. 77:205-216.

Mertens, D. R. 1997. Creating a system for meeting the fiber requirements of dairy cows. J. Dairy Sci. 80:1463-1481.

NRC. 2001. Nutrient Requirements of Dairy Cattle. 7th rev. ed. Natl. Acad. Press, Washington, DC.

Nuez Ortin, W. G., and P. Yu. 2009. Nutrient variation and availability of wheat DDGS, corn DDGS and blend DDGS from bioethanol plants. J. Sci. Food Agric. 89:1754-1761.

Oba, M., and M. S. Allen. 2003. Effects of corn grain conservation method on ruminal digestion kinetics for lactating dairy cows at two dietary starch concentrations. J. Dairy Sci. 86:184-194.

Palmquist, D. L., and H. R. Conrad. 1978. High fat rations for dairy cows. Effects on feed intake, milk and fat production and plasma metabolites. J. Dairy Sci. 61:890-901.

Penner, G. B., K. A. Beauchemin, and T. Mutsvangwa. 2006. An evaluation of the accuracy and precision of a stand-alone submersible continuous ruminal $\mathrm{pH}$ measurement system. J. Dairy Sci. 89:2132-2140.
Penner, G. B., and M. Oba. 2009. Increasing dietary sugar concentration may improve dry matter intake, ruminal fermentation, and productivity of dairy cows in the postpartum phase of the transition period. J. Dairy Sci. 92:3341-3353.

Penner, G. B., P. Yu, and D. A. Christensen. 2009. Effects of replacing forage or concentrates with wet or dry distillers' grains on the productivity and chewing activity of dairy cattle. Anim. Feed Sci. Technol. 153:1-10.

Peterson, D. G., E. A. Matitashvili, and D. E. Bauman. 2003. Dietinduced milk fat depression in dairy cows results in increased trans-10, cis-12 CLA in milk fat and coordinate suppression of mRNA abundance for mammary enzymes involved in milk fat synthesis. J. Nutr. 133:3098-3102.

Sasikala-Appukuttan, A. K., D. J. Schingoethe, A. R. Hippen, and K. F. Kalscheur. 2008. The feeding value of corn distillers solubles for lactating dairy cows. J. Dairy Sci. 91:279-287.

Schingoethe, D. J., M. J. Brouk, and C. P. Birkelo. 1999. Milk production and composition from cows fed wet corn distillers grains. J. Dairy Sci. 82:574-580.

Smith, W. A., B. Harris Jr. H. H. Van Horn, and C. J. Wilcox. 1993. Effect of forage type on production of dairy cows supplemented with whole cottonseed, tallow, and yeast. J. Dairy Sci. 76:205215.

Stone, W. C. 2004. Nutritional approaches to minimize subacute ruminal acidosis and laminitis in dairy cattle. J. Dairy Sci. 87(E Suppl.)E13-E26.

Tyrrell. H. F., and P. W. Moe. 1975. Effect of intake on digestive efficiency. J. Dairy Sci. 58:1151-1163.

Tyrrell, H. F., and J. T. Reid. 1965. Prediction of the energy value of cow's milk. J. Dairy Sci. 48:1215-1223.

Udén, P., P. E. Colucci, and P. J. Van Soest. 1980. Investigation of chromium, cerium and cobalt as markers in digesta. Rate of passage studies. J. Sci. Food Agric. 31:625-632.

Van Soest, P. J., J. B. Robertson, and B. A. Lewis. 1991. Methods for dietary fiber, neutral detergent fiber and non-starch polysaccharide in relation to animal nutrition. J. Dairy Sci. 74:3583-3597.

Vander Pol, K. J., M. K. Luebbe, G. I. Crawford, G. E. Erickson, and T. J. Klopfenstein. 2009. Performance and digestibility characteristics of finishing diets containing distillers grains, composites of corn processing coproducts, or supplemental corn oil. J. Anim. Sci. $87: 639-652$.

Voelker, J. A., and M. S. Allen. 2003a. Pelleted beet pulp substituted for high moisture corn: 1. Effects on feed intake, chewing behavior, and milk production of lactating dairy cows. J. Dairy Sci. $86: 3542-3552$

Voelker, J. A., and M. S. Allen. 2003b. Pelleted beet pulp substituted for high-moisture corn: 2. Effects on digestion and ruminal digestion kinetics in lactating dairy cows. J. Dairy Sci. 86:3553-3561.

Wildman, E. E., G. M. Jones, P. E. Wagner, R. L. Boman, H. F. Trout Jr., and T. N. Lesch. 1982. A dairy cow body condition scoring system and its relationship to selected production characteristics. J. Dairy Sci. 65:495-501.

Williams, C. H., D. J. David, and O. Iismaa. 1962. The determination of chromic oxide in faeces samples by atomic absorption spectrophotometry. J. Agric. Sci. 59:381-385.

Yang, W. Z., and K. A. Beauchemin. 2007. Altering physically effective fiber intake through forage proportion and particle length: digestion and milk production. J. Dairy Sci. 90:3410-3421.

Yang, W. Z., and K. A. Beauchemin. 2009. Increasing physically effective fiber content of dairy cow diets through forage proportion versus forage chop length: Chewing and ruminal pH. J. Dairy Sci. 92:1603-1615. 